\title{
COVID-19 AS A GLOBAL DISASTER: Challenges to risk governance and social vulnerability in Brazil
}

\author{
Carlos Machado de Freitas \\ Isadora Vida de Mefano e Silva \\ Natália da Cunha Cidade
}

${ }^{1}$ Center for Studies and Research in Health Emergencies and Disasters / Oswaldo Cruz Foundation / National School of Public Health Rio de Janeiro/RJ - Brasil

D ${ }^{\text {II }}$ Center for Studies and Research in Health Emergencies and Disasters / Oswaldo Cruz Foundation / National School of Public Health Rio de Janeiro/RJ - Brasil

III Center for Studies and Research in Health Emergencies and Disasters / Oswaldo Cruz Foundation / National School of Public Health Rio de Janeiro/RJ - Brasil

\begin{abstract}
On March 11 2020, the Director of the World Health Organization characterized the Public Health Emergency by COVID-19 as a pandemic (PAHO, 2020). In this article we understand this pandemic as a Global Disaster that can evolve into a Complex Emergency presenting risks for a Humanitarian Crisis in many countries, including Brazil. In this context we face two challenges: the governance of risks and coping and reducing vulnerabilities. In Brazil political, social and economic threats overlap with the dangers caused by the Sars-Cov-2 virus. These threats undermine the capacity for risk governance and widen and intensify social inequalities, making Brazil the new epicenter of the global disaster by COVID-19.
\end{abstract}

Keywords: Disaster. Pandemic. COVID-19. Vulnerabilities.

São Paulo. Vol. 23, 2020

\section{Debating ideas}

The COVID-19 epoch: Interdisciplinary research towards a new just and sustainable ethics

DOI: http://dx.doi.org/10.1590/1809-4422asoc20200115vu2020L3ID 


\section{INTRODUCTION}

On March 11, 2020, the World Health Organization (WHO) announces the COVID-19 outbreak as a pandemic. The first lesson we learn is that new hazards concerning viruses, such as SARS-CoV-2, producing new diseases (such as COVID-19, as well as SARS and MERS in the past), will continue to occur.

In addition to that, there are new disasters of natural and technological origin, or the combination of both, such as the earthquake and tsunami that damaged the Fukushima Power plant, resulting in the nuclear disaster. Some situations may trigger an overlap of epidemics, natural and/or technological disasters and humanitarian crisis, leading to complex emergencies (LUCCHINI et al., 2017).

In this article we understand this pandemic as a global disaster that can evolve into a complex emergency presenting risks for a humanitarian crisis in many countries, including Brazil. In this context we face two challenges: the governance of risks and coping and reducing vulnerabilities.

\section{THE COVID-19 PANDEMIC AS A GLOBAL DISASTER}

According to the United Nations Office for Disaster Risk Reduction (UNDRR), disaster is any event or situation including those related to biological hazards and pandemics, that result in a serious disruption of the functioning of a community or society exceeding the ability of it to respond using its own resources. The disaster involves exposure to a hazard, conditions of vulnerability and low capacity to cope with the potential negative consequences which when combined may result in health impacts (diseases and deaths) and social and economic losses.

The COVID-19 pandemic combines these characteristics and should be treated as a global disaster. The comprehension of it as a global disaster demands focusing on important aspects, which means the combination of several processes, from the global to the local level as shown in Figure 1. 


\section{Figure 1: Risk drivers, poverty and COVID-19 pandemic impacts}

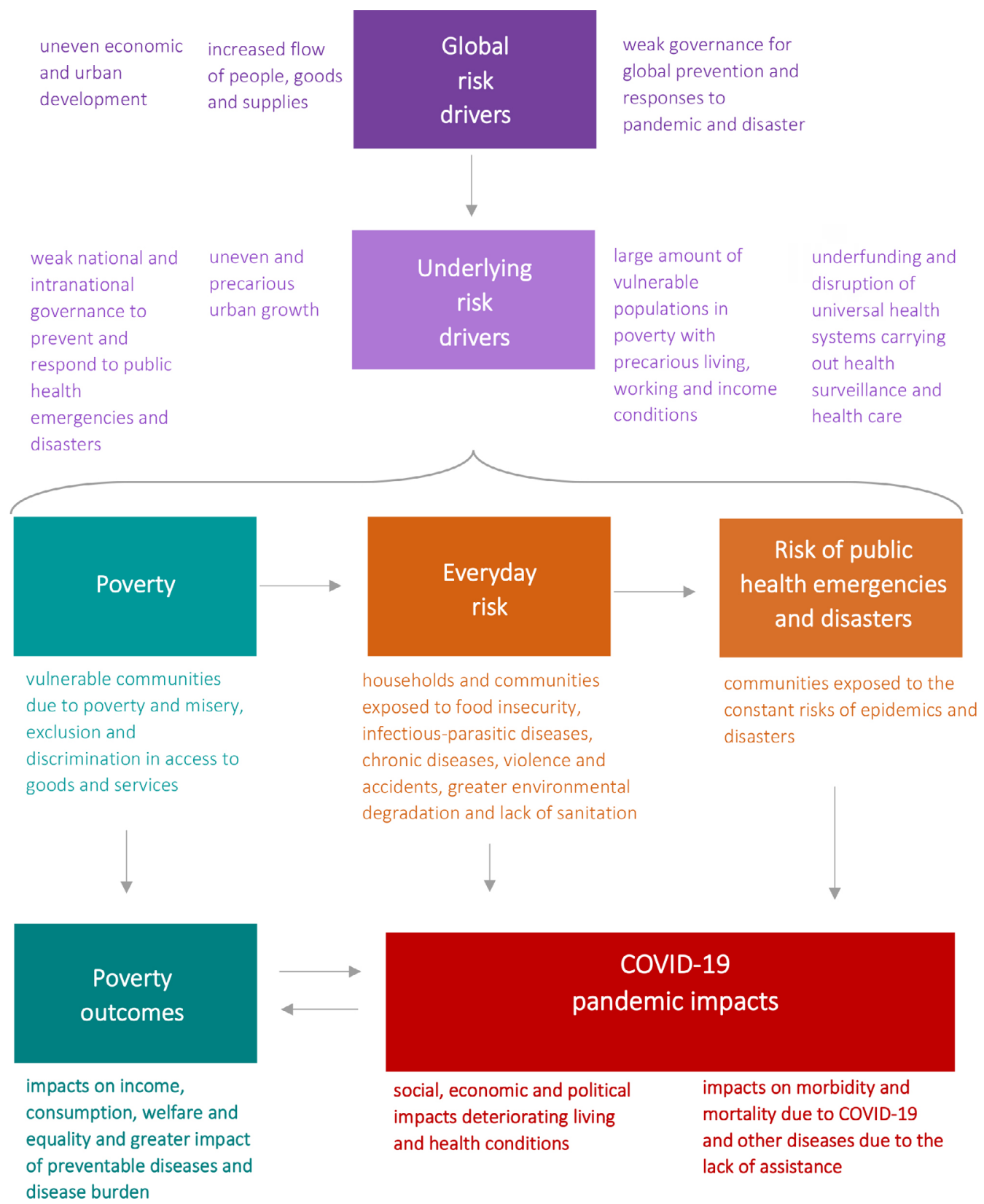

Source: adapted from ISDR (2009) Global Assessment Report on Disaster Risk Reduction - Risk and poverty in a changing climate: Invest today for a safer tomorrow. 
The first aspect to consider is SARS-CoV-2 as a hazard; its fast circulation and spread due to intensification of global flows of people and goods leading to an exposure of the world population to a new virus without immunity. Added to this, two other combined processes at the global level are recognized. On one hand, a model of economic inequality, income concentration and growing poor population exists, increasingly concentrated in urban areas and their peripheries, in precarious living conditions. On the other hand, is the weakening of institutions and capacities of global governance to deal with disasters and pandemics that require coordinated policies and actions.

These global driving forces have been reproduced at national levels, and in countries that are on the periphery of the global economic system, such as Brazil. These processes have intensified social inequalities and income concentration resulting in a large vulnerable population with precarious living, working and income conditions. The vulnerable population is the most dependent on the actions carried out by universal health systems, such as the Brazilian Unified Health System (SUS), healthcare for groups at higher risk of COVID-19, such as the elderly, people with chronic diseases (diabetic, hypertensive, cardiac insufficiency, renal or chronic respiratory disease). They are also the ones who will suffer disproportionately from the impacts of the Coronavirus disease due to the underfunding and destructuring of SUS within its health surveillance, testing and tracking capacities, as well as healthcare, from primary healthcare to hospitals and ICUs (FREITAS et al., 2020).

In the last ten years, despite a set of laws and regulations in the country created to strengthen the capacity to prevent and respond to disasters and emergencies in public health after floods and landslides in January 2011 in Rio de Janeiro with thousands of people affected and 918 deaths, Brazil has experienced the dismantling of environmental agencies, the stagnation of the strengthening of civil defense agencies and the underfinancing and destructuring of the public health system. The result of this process undermines response capacity and health risk reduction, which should be considered among other aspects of the health infrastructure.

The daily risks associated with infectious-parasitic diseases related to precarious living conditions and sanitation, as well as chronic diseases, violence and accidents, will not stop during the pandemic. It means that COVID-19 brings new risk scenarios and worsening health situations, compromising the health sector's response to everyday risks and may overlap risks of new health emergencies and disasters that may occur during the pandemic.

As an example, we take the state of Amazonas, which has 62 municipalities. On May 13, more than half of the 20 municipalities with the highest number of cases (incidence) and deaths (mortality) per 100,000 inhabitants in Brazil, were identified in the state $(G 1,2020)$. The concentration of Amazonas' hospital structures able to deal with COVID-19 are in a single municipality, Manaus, the capital. Within a state whose territorial extension $\left(1,571,000 \mathrm{~km}^{2}\right)$ is larger than those of the United Kingdom, Italy and France combined $\left(1,187,634 \mathrm{~km}^{2}\right)$, this concentration represents a lack of health infrastructure for the other 61 municipalities. It also represents the impairment of the 
capacity to take care of everyday problems as the pandemic affects populations and health professionals in the most distant municipalities. At the same time, we should consider that June and July are the months of floods affecting riverside populations, located in the most distant municipalities (sometimes up to $1000 \mathrm{~km}$ ). River boat trips (the main means of transport) to access these places can last up to three days, and the food and nutritional security of these communities is already beginning to be critical (TREGIDGO et al., 2020). By considering the overlap of COVID-19, healthcare, flooding, food security and nutrition with everyday health problems in such situations, it is clear that the impacts of the pandemic go far beyond those caused by the SARS-CoV-2 virus.

\section{THE CHALLENGE OF RISK GOVERNANCE}

In general, disasters - and more precisely global disasters, such as the one caused by the COVID-19 pandemic - require urgent decisions under uncertain conditions. Also, it should be taken into account national and local heterogeneity, social and political competing interests with short and long term impacts, leading to an extremely complex risk management and governance of these events.

The complexity of such an event accentuates the need for a risk governance that ensures the coordination of risk management in order to support countries, states and municipalities. The health sector plays a key leadership role in the risk management of a pandemic, a process that includes and depends on the participation of the entire society. This participation considers the civil society (NGOs, residents' associations, local movements such as the ones in favelas and indigenous communities, among others) and other government sectors relevant to response (Civil Defense, economy, education, transportation, water and sanitation, environment, social protection, agriculture, among others). In order to work in a coordinated way, it is necessary for all these actors' coherence in the actions and messages to gain people's confidence, which is a prerequisite for risk governance (DE MARCHI; RAVETZ, 1999).

In an extreme situation such as the COVID-19 pandemic, risk governance depends on this congruence expressed in the coherence of official documents, press conferences and actions carried out by the health sector, as well as different governmental sectors. In particular, the one who, in any democratic country should express leadership in the face of a pandemic, the president. The lack of coherence within the Brazilian government through contradictory or inapplicable messages results in an incomplete response to the pandemic. This position interferes negatively and delays the impact of lifesaving measures and weakens confidence in the healthcare sector, which plays a key leadership role in the pandemic.

If congruence and reliability are essential prerequisites for good risk governance, we can only observe that contradictory or inapplicable messages go far beyond the lack of coherence within a government, as is the case in Brazil. They reflect a political dis- 
pute in which a serious health crisis can be overlapped by a political crisis ${ }^{1}$, extending and amplifying the negative impacts of the COVID-19 pandemic. In the U.S., President Trump allowed governors to make their own decisions, in part because they have greater control over actions within the states, such as those related to police power to shut businesses and enforce curfews. But many governors and local authorities were reluctant to invoke these powers when they considered that they could suffer the political costs of the measures with no clear guidance from the federal government (CORNWALL et al., 2020). On the contrary, in Brazil, the president has been threatening to edit a decree to prevent the autonomy of states and municipalities to issue social distance measures and, at the same time, boycotting them through presidential decrees that amplify what is considered essential activities, including religious centers (decree of March 26), fitness centers, beauty salons and barbershops (decree of May 11).

The result of this process is dysfunctional risk management and governance. On one hand, the health sector is adopting and proposing risk management measures that relate to social distancing, on the other hand, the president of the republic is adopting contradictory and conflicting measures and messages, eroding the conditions for risk governance.

On March 25, the National Council of Municipal Health Secretariats (CONASEMS) published a "Position note on the COVID-19 pandemic and measures of social isolation," alerting to the need for stability in the health system governance arenas (CONASEMS, 2020). This note highlights a context of political conflicts during the pandemic, with the Brazilian president leading speeches and actions incongruent with the recommendations held by the WHO and the country's Health Ministry. Such levels of incongruity and instability led to more political, social and economic instability, and resulted in the resignation of two health ministers in less than a month, Luiz Mandetta on April 16, and Nelson Teich on May 15.

Congruence in governmental measures and actions, as well as political stability within the principles of a democratic society, are prerequisites for management and governance in the context of a pandemic, such as the one we are experiencing. None of them is being offered by the presidency who seems unable to lead governance for the response to the pandemic based on scientific evidence and the experience of other countries in facing the risks and impacts of COVID-19. In the current Brazilian scenario, the advances of the pandemic, which already place Brazil in the sixth world position in number of cases and deaths and as a new epicenter of this global disaster (WALTER, 2020), combine not only the hazard of the SARS-CoV-2 virus, but also threats to the democratic system as a prerequisite for risk governance.

1- This political crisis involved disputes within the government resulting in the departure of two ministers of health and the minister of justice, followed by conflicts between the executive, legislative and judicial branches. 


\section{THE CHALLENGES OF SOCIAL VULNERABILITY}

Disasters in general, and most notably a global disaster such as the one caused by the COVID-19 pandemic, due to its dynamics and characteristics that demand decisions under conditions of urgency and uncertainty, require not only congruence and trust, but also expansion of social participation and shared knowledge. They allow for incorporating both the daily experiences of communities as a part of facing current vulnerabilities, and better preparation and alert for future risks. In this perspective, returning to "normal" does not mean returning to the same conditions of risk and vulnerabilities that led to the greatest impact of this disaster on peripheral areas and poorer populations (UNDRR, 2020).

Brazil is a country of vast dimensions and with great heterogeneity in its socioeconomic and cultural contexts, as well as regional and intraregional inequalities, making the country 7th in terms of social inequalities in the world (UNDP, 2019). These massive inequalities result in social vulnerabilities that, in a disaster scenario like the one caused by the COVID-19 pandemic, expand the potential impacts on human health expressed in morbidity and mortality for the poorest and most miserable populations, for whom the social and economic impacts tend to be larger and more durable, as has happened in Spain (BURGEN; JONES, 2020) and in the United States (DORN et al., 2020).

In Brazil, many of the social distance and hygiene measures adopted to face the pandemic are not feasible or only partially applicable in the areas where the poorest populations live. Freitas et al., (2020) estimate that between 12.7 and 18.2 million people live in subnormal agglomerates (also known as slums - "favelas" - which combine characteristics such as narrow and irregular circulation routes, precarious housing and an insufficient supply of essential public services, such as water supply). In addition to this amount, Natalino (2016) estimated that in 2015 there were 101,854 homeless people in Brazil, living in unhealthy, insecure conditions and with precarious access to basic services. In the most populous city in the country this population had a growth of $53 \%$ in the last few years (AGÊNCIA BRASIL, 2020).

In addition to precarious and overcrowded housing conditions that make social distancing measures unenforceable, another fundamental issue is sanitation and access to water, which are extremely necessary in a pandemic situation. As indicated by the WHO (2020), the provision of water, sanitation and hygiene measures is essential to provide adequate care in all outbreaks of infectious diseases, as well as to guarantee conditions for the application of hygiene practices in communities, homes, schools, commerce and healthcare facilities, among others, helping to reduce the transmission of COVID-19.

The WHO guidelines for waste management and surface cleaning taking into account the survival time of the virus in materials and environments, hand hygiene practices, domestic cleaning, among others, are fundamental, but unworkable for millions of Brazilians. In Brazil, according to data from the National Sanitation Information System (SNIS) from 2018, 39.4 million people (16.4\% of the Brazilian population) were not served by treated water supply systems, and a large percentage of these people overlap precisely with those related to resident populations of subnormal agglomerates and peripheries. It is also important to highlight the difference in access to this service in the 
Brazilian states: those in the Southeast region, numbering $91.03 \%$ of the population, are supplied with treated water; in the North, this number drops to 57.05\% (SNIS, 2018).

Another example of the limits of many measures is found in the reorganization of the functioning of public transport, aimed at social distancing. In the city of São Paulo, during the critical week to stop the transmission of the coronavirus, the public transport management company reduced the fleet in circulation by $60 \%$ (BONDUKI, 2020). This measure, adopted with the objective of reducing the flow and movement of people on the streets, ended up resulting in an inverse effect, with agglomerations at bus stops and public transport, affecting mainly the poorest population, concentrated on the peripheries, totally dependent on public transport and integrating the contingent of people who, without emergency financial aid from the government, will continue to go to the streets in the search for work and income.

Given the context of the pandemic and its most serious impacts on slums, several communities have been organizing and creating possibilities for greater participation in the management processes and also the governance of COVID-19 risks, the result of a wide range of social movement initiatives in the country's peripheries and slums.

The lack of a specific position by the federal government for the situation of such areas leading to self-management initiatives by popular movements highlights two aspects. It shows, on the one hand, the absence of state and municipal policies that take into account these vulnerabilities, and on the other hand, the capacity for local and regional management, pointing to ways that can be incorporated by public policy. The proposed measures include concrete actions, such as the distribution of hygiene products and basic food baskets, but also more general proposals such as the repeal of constitutional measures that limit public spending in social protection and which provide for the suspension of the employment contract and salary (OLIVEIRA, 2020).

In Paraisópolis, a favela in São Paulo, the residents realized the magnitude of the pandemic and the lack of public policies aimed at their reality and decided to undertake their own coping management. In this process, volunteers were trained to be "street presidents," each with the following tasks: to monitor and raise awareness to the householder about the virus' impacts so that he/she remains at home; to distribute donations and avoid agglomerations due to its deliveries; to call for help, if necessary, in cases of symptoms of COVID-19 or other diseases; and to bring news from reliable sources and fight fake news. In addition, and through donations, the community association hired, through a private company, three ambulances: two of them are basic, and one is ICU. In addition to the structures, Paraisópolis has two doctors, three nurses and two rescuers - all on-call to supply the community 24 hours a day. At the request of the association, two state schools were allocated by the Department of Education. The spaces will house 500 beds for residents who have the new coronavirus, or those suspected (VESPA, 2020).

In Rio de Janeiro, the favelas movement produced the "Covid Action Plan in the Favelas of Rio de Janeiro: a catastrophe to be avoided," (ABRASCO, 2020), with an act and delivery to state and municipal health managers and other sectors. 


\section{FINAL CONSIDERATIONS}

COVID-19 will not be the last pandemic. So that this global disaster and other futures do not turn into a humanitarian crisis, we are facing a challenge that requires profound changes in the driving forces that produce global disasters through inequities and vulnerabilities, as well as the reduction of national and international risk reduction governance capacities.

We live in a context in Brazil where the threats of the political, social and economic have intersected with the hazards caused by the SARS-CoV-2 virus. These threats undermine risk governance capabilities and widen and intensify social inequalities, making Brazil the new epicenter of the global disaster by COVID-19 and a potential humanitarian crisis in poor areas (WALTER, 2020).

\section{REFERENCES}

ASSOCIAÇÃO BRASILEIRA DE SAÚDE COLETIVA. Movimentos de favelas organizam plano de ação e reivindicam compromisso público no Rio de Janeiro. Rio de Janeiro, 2020. Available at: <https:/www.abrasco.org.br/site/wp-content/uploads/2020/05/PlanodeAcao_COVID19-e-FAVELAS-RJ.pdf> Access: May. 08. 2020.

AGÊNCIA BRASIL. População de rua em SP aumenta 53\% em 4 anos e chega a 24 mil pessoas. 11,7 mil pessoas dormem em abrigos e 12,6 mil estão em calçadas ou sob viadutos. Exame, São Paulo, 31 Jan 2020. Available at: <https://exame.abril.com.br/brasil/populacao-de-rua-em-sp-aumenta-53-em-4-anos-e-chega-a-24-mil-pessoas> Access: April. 01. 2020.

BONDUKI, N. Reduzindo a frota de ônibus, prefeitura agravou o risco de contaminação durante a semana crítica da pandemia. Folha de São Paulo, 6 Abr 2020. Available at: https://www1.folha. uol.com.br/colunas/nabil-bonduki/2020/04/reduzindo-a-frota-de-onibusprefeitura-agravou-o-risco-de-contaminacao-durante-a-semana-critica-da-pandemia.shtml Access: April. 04. 2020

BURGEN, S.; JONES, S. Poor and vulnerable hardest hit by pandemic in Spain. Rate of infection in working class areas in and around Barcelona is nearly seven times higher than upmarket áreas. The Guardian, 1 Abr 2020. Available at:

$<$ https://www.theguardian.com/world/2020/apr/01/poor-and-vulnerable-hardest-hit-by-pandemic-in-spain> Access: April. 08. 2020.

CONSELHO NACIONAL DE SECRETARIAS MUNICIPAIS DE SAÚDE. Nota de Posicionamento sobre a pandemia de COVID-19 e medidas de isolamento social. Brasília, 25 mar 2020. Available at: <https://www.conasems.org.br/nota-posicionamento-sobre-a-pandemia-decovid-19-e-medidas-de-isolamento-social> Access: April. 08. 2020..

CORNWALL, W. et al. The United States leads in coronavirus cases, but not pandemic response. Science News Staff, 2020. Available at: < https://www.sciencemag.org/news/2020/04/united-states-leads-coronavirus-cases-not-pandemic-response> Access: April. 08. 2020. 
DE MARCHI, B; RAVETZ, J. Risk management and governance: a post-normal Science approach. 1999. Futures v. 31, p. 743-757. https://doi.org/10.1016/S0016-3287(99)00030-0

DORN, A. V.; COONEY, R. E.; SABIN, M. L. COVID-19 exacerbating inequalities in the US. The Lancet, 18 Abr 2020. v. 395. Available at: < https://www.thelancet.com/journals/lancet/article/PIIS0140-6736(20)30893-X/fulltext\#\%20> Access: April. 20. 2020.

FREITAS, C. M. et al. A Gestão de Riscos e Governança na Pandemia por COVID-19 no Brasil: análise dos decretos estaduais no primeiro mês. Relatório Técnico. Rio de Janeiro, 2020. Available at: https://portal.fiocruz.br/noticia/relatorio-da-fiocruz-discute-isolamento-social-e-gestao-de-riscos Access: May. 16. 2020.

FREITAS, C. M. et al. Conquistas, limites e obstáculos à redução de riscos ambientais à saúde nos 30 anos do Sistema Único de Saúde. Ciênc. saúde coletiva, 2018. v. 23, n. 6, p. 1981-1996. Available at: https://doi.org/10.1590/1413-81232018236.04702018.

G1. Casos de coronavírus e número de mortes no Brasil em 13 de maio: As secretarias estaduais de Saúde confirmam no país 190.137 casos do novo coronavírus (Sars-CoV-2), com 13.240 mortes.13 das 20 cidades com maior mortalidade estão no Amazonas. G1, 13 Mai 2020. Available at: <https:/g1.globo.com/bemestar/coronavirus/noticia/2020/05/13/casos-de-coronavirus-e-numero-de-mortes-no-brasil-em-13-de-maio.ghtml> Access: May. 15. 2020.

ISDR (2009) Global Assessment Report on Disaster Risk Reduction - Risk and poverty in a changing climate: Invest today for a safer tomorrow. United Nations, Geneva, Switzerland. Available at: <https://www.undrr.org/publication/global-assessment-report-disaster-risk-reduction-2009> Access: May. 01. 2020.

LUCCHINI, R. G. et al. A comparative assessment of major international disasters: the need for exposure assessment, systematic emergency preparedness, and lifetime health care. BMC Public Health, 2017. v. 17, n. 46.

Available at: <https://doi.org/10.1186/s12889-016-3939-3> Access: April. 12. 2020.

NATALINO, M. A.C. Estimativa da população em situação de rua no Brasil. IPEA, 2016. Available at: https://www.ipea.gov.br/portal/index.php?option $=$ com_content\&view $=$ article $\&$ id $=28819$ Access: April. 05. 2020.

OLIVEIRA, C. Movimentos populares elaboram 20 propostas contra a pandemia de covid-19: Entidades apontam medidas a serem tomadas pelo governo para a proteção das populações que estão nas bases, nas favelas e periferias e também das classes mais privilegiadas. Brasil de Fato, 30 Mar 2020. Available at:

< https://www.redebrasilatual.com.br/cidadania/2020/03/movimentos-populares-elaboram-20-propostas-contra-a-pandemia-de-covid-19/>

Access: April. 1. 2020.

SISTEMA NACIONAL DE INFORMAÇÕES SOBRE SANEAMENTO. Painel de Informações Sobre Saneamento. Brasil, 2018. Available at: <http://www.snis.gov.br/> Access: April. 10. 2020 . 
TREGIDGO, D.; PARRY L.; TORRES P. C. The worst time for a pandemic - how coronavirus and seasonal floods are causing hunger in the remote Amazon. The Conversation, 2020. Available at: <https://theconversation.com/the-worst-time-for-a-pandemic-how-coronavirus-and-seasonal-floods-are-causing-hunger-in-the-remote-amazon-137729> Access: May. 15. 2020.

UNITED NATIONS DEVELOPMENT PROGRAMME. 2019 Human Development Report. Nova York, 2019. Available at: http://hdr.undp.org/sites/default/files/hdr2019.pdf Access: April. 01. 2020

UNITED NATIONS OFFICE FOR DISASTER RISK REDUCTION. UNDRR Initial COVID-19 Engagement Strategy and Communication Campaign. Available at: http://www.irdrinternational.org/2020/04/10/undrr-initial-covid-19-engagement-strategy-and-communication-campaign/: March. 18. 2020. Access: April. 01. 2020

VESPA, T. Paraisópolis monitora 21 mil casas com presidentes de rua e médico próprio. UOL, São Paulo, 15 Abr 2020. Available at:

$<$ https://noticias.uol.com.br/saude/ultimas-noticias/redacao/2020/04/15/paraisopolis-contra-covid-favela-tem-presidentes-de-rua-e-sistema-de-saude.htm> Access: April. 15. 2020.

WORLD HEALTH ORGANIZATION. Technical brief - Water, sanitation, hygiene and waste management for COVID-19. Geneva, 2020. Available at: https:/www.who.int/publications-detail/water-sanitation-hygiene-and-waste-managementfor-covid-19 Access: April. 10. 2020

WALTER, J. D. Coronavirus pandemic: Is Brazil the new epicenter? Scientific models have suggested more people may be infected with COVID-19 in Brazil than in the US. Politicians are divided about what to do, but experts say none has an effective strategy. DWNews, 13 Mai 2020. Available at: <https://p.dw.com/p/3cBQi> Access: May. 15. 2020. 
Carlos Machado de Freitas

$\square$ carlos.freitas@ensp.fiocruz.br

ORCiD: https://orcid.org/0000-0001-6626-9908

Isadora Vida de Mefano e Silva

$\square$ isadoramefano@gmail.com

ORCiD: https://orcid.org/0000-0001-9946-5147

\section{Natália da Cunha Cidade}

$\square$ nataliadacunhacidade@gmail.com

ORCiD: https://orcid.org/0000-0001-8563-9230
Submitted on: 08/06/2020

Accepted on: 10/06/2020

2020;23:e0114

How to cite: FREITAS, C. M.; SILVA, I. V. M.; CIDADE, N. C. COVID-19 As a Global Disaster - Challenges to Risk Governance and Social Vulnerability in Brazil. Ambiente \& Sociedade. São Paulo, v. 23, p. 1-12, 2020. 


\title{
A COVID-19 COMO UM DESASTRE GLOBAL: desafios à governança de risco e vulnerabilidade social no Brasil
}

\author{
Carlos Machado de Freitas \\ Isadora Vida de Mefano e Silva \\ Natália da Cunha Cidade
}

São Paulo. Vol. 23, 2020

Ideias em debate

A época $\mathrm{CO}$. VID-19: Pesquisa interdisciplinar e uma nova ética sustentável e justa
Resumo: Em 11 de março, o Diretor da Organização Mundial da Saúde caracterizou a Emergência em Saúde Pública por COVID-19 como uma pandemia (OPAS, 2020). Neste artigo compreendemos essa pandemia como um Desastre Global que pode evoluir para uma Emergência Complexa envolvendo o potencial de uma Crise Humanitária em muitos países, incluindo o Brasil. Dois desafios se colocam neste contexto: o da governança dos riscos e do enfrentamento e redução das vulnerabilidades. Vivemos em um contexto no Brasil onde as ameaças políticas, sociais e econômicas se sobrepuseram aos perigos causados pelo vírus Sars-Cov-2. Essas ameaças minam a capacidade de governança de risco e ampliam e intensificam as desigualdades sociais, tornando o Brasil o novo epicentro do desastre global pela COVID-19.

Palavras-chave: Governança do Risco. Desastres. Pandemia. CO. VID-19. Vulnerabilidade.

Como citar: FREITAS, C. M.; SILVA, I. V. M.; CIDADE, N. C. A COVID-19 COMO UM DESASTRE GLOBAL: desafios à governança de riscos e vulnerabilidade social no Brasil. Ambiente $\mathbb{\&}$ Sociedade. São Paulo, v. 23, p. 1-12, 2020. 


\title{
LA PANDEMIA POR COVID-19 COMO UN DESASTRE MUNDIAL: Vulnerabilidad social y desafíos para la gobernanza de riesgos en Brasil
}

\author{
Carlos Machado de Freitas \\ Isadora Vida de Mefano e Silva \\ Natália da Cunha Cidade
}

São Paulo. Vol. 23, 2020

Ideas en debate

La época CO. VID-19: investigación interdisciplinaria y una nueva ética sostenible y justa
Resumen: El 11 de Marzo, el Director de la Organización Mundial de la Salud calificó la Emergencia de Salud Pública de COVID-19 como una pandemia (OPS, 2020). En este artículo, entendemos la pandemia como un Desastre Global que puede evolucionar en una Emergencia Compleja involucrando el potencial de una Crisis Humanitaria en muchos países, incluido Brasil. En este contexto surgen dos desafíos: la gobernanza del riesgo y combate y redución de las vulnerabilidades. Vivimos en un contexto en Brasil donde las amenazas políticas, sociales y económicas han superado los peligros causados por el virus Sars-Cov-2. Estas amenazas socavan la capacidad de gobernanza del riesgo y amplían e intensifican las desigualdades sociales, convirtiendo a Brasil en el nuevo epicentro del desastre mundial por COVID-19.

Palabras clave: Gobernanza del Riesgo. Desastres. Pandemia. COVID-19. Vulnerabilidad

Como citar: FREITAS, C. M.; SILVA, I. V. M.; CIDADE, N. C. LA PANDEMIA POR COVID-19 COMO UN DESASTRE MUNDIAL: Vulnerabilidad social y desafíos para la gobernanza de riesgos en Brasil. Ambiente \& Sociedade. São Paulo, v. 23, p. 1-12, 2020.

DOI: http://dx.doi.org/10.1590/1809-4422asoc20200115vu2020L3ID 